\title{
Interactive comment on "Using GRACE to derive corrections to precipitation data sets and improve modelled snow mass at high latitudes" by Emma L. Robinson and Douglas B. Clark
}

\section{Anonymous Referee \#1}

Received and published: 8 June 2019

Please see comments on the attached pdf file.

Please also note the supplement to this comment:

https://www.hydrol-earth-syst-sci-discuss.net/hess-2019-109/hess-2019-109-RC1-

supplement.pdf

Interactive comment on Hydrol. Earth Syst. Sci. Discuss., https://doi.org/10.5194/hess-2019- 